\title{
Understanding the HRM Role in MNCs from a Social Capital Perspective
}

\author{
Article by Joshua Akanyonge \\ Ph.D in Management, Texila American University, Ghana \\ E-mail: joshkan@yahoo.com
}

\begin{abstract}
The purpose of this study is two-fold: to investigate the degree to which the formal structure of the HR organization is reflected in the concrete activities of the HR function; and to explore the extent to which social capital, as a resource, impacts on the actual HR functional activities. The study sought to contribute to our knowledge of HR functional roles in MNCs by taking into account how social capital may operate on the enacting of these roles. Most prior studies have concentrated on HR roles, instead of ascertaining role performance from HR professionals' actual day-to-day activities. Knowing what HR professionals actually do is the strongest gauge for determining if the function is strategically aligned to serving line needs or not. This study aimed to employ social capital as a tool to conceptualize HR formal roles versus actual activities in an exploratory setting. It was based on a single case study of an MNC subsidiary. A total of 10 interviews were conducted. The finding showed the HR function was highly evaluated for administrative tasks. However, strong callswere made on HR to increase their involvement with a particular focus on activities related to the business support role. There appeared to be a connection between HR social capital and the actual activities of the HR organization. Although strong formal linkages between the HR function and line management were evident, the level of informal relationships was weak between them. This is a slice of case study research in a subsidiary, and therefore the findings may not be generalizable. Further quantitative research is recommended. The practical implication for HR professionals is that careful consideration should be taken in observing how social capital between the HR function and the larger organization adds value.
\end{abstract}

Keywords: HRM, HR roles, social capital theory, case study

\section{Introduction}

Although much has been written about the HR organization in extant literature, a careful examination of the literature exposes a striking lack of coverage of vital issues regarding the function. As a consequence, a couple of salient questions remain either unsatisfactorily considered or unanswered. Foremost, how are HR departments organized, and why? As the scope of the human resources work has evolved from the initial personnel administration department into the more strategic focus, in the same way has our understanding of both the structure and the roles of the HR organization remain painfully indistinct(Caldwell and Storey, 2007). Recently, HR work has been split along transformational (strategic) and transactional lines(Gratton, 2003; Wright, 2008), thus presenting mounting challenges respecting the optimal way to organize the HR function. Nonetheless up-to-date, there has been little research on the HR structural models employed in organizations, the exact ways by means of which the HR department accomplishes its sphere of services to the organization(Guest and King, 2004), and the motivation for their usage.

A second issue is, regardless of the choices concerning the HR structure and service delivery, they should have a direct bearing for the roles of the HR profession in an organization. Nevertheless, to what level are these formal roles reflected in the actual activities of HR professionals? Past research has formulated diverse typologies concerning the different roles that could be enacted by HR professionals (Ulrich and Brockbank, 2005). 
These efforts were backed by an insistence that the HR function become more strategic or business focused. However, majority of extant literature is largely normativein kind and/or founded on notional typologies of the roles played by the HR profession. In line with a growing body of research focused on strategy-as-practice in the strategy field (e.g. Jarzabkowski, Balogun, and Seidl, 2007; Golsorkhi, Rouleau, Seidl, and Vaara, 2010), there is a pressing necessity to increase our understanding of what activities are actually undertaken by HR departments. In other words, what kind of activities take place within the daily work of the HR function, do these correspond with formal HR structures and firm strategy, and which of these activities are perceived to add value?

In recent times, a growing body of research has emphasized the importance of leveraging social capital within and across units in an organization. Social capital can contribute to the successful performance of MNCs in several ways (Taylor, 2007). The designation social capital refers tothe gains that accrue from the links and informal relationships of people inside an organization and outside (Kostova and Roth, 2003). It refers to the stores of trust, norms and networks that individuals can use for overcoming common hurdles. Social capital is described as having three components:structural, cognitive and relational forms (Nahapiet and Ghoshal, 1998). The structuralsocial capital is founded upon the network of people one knows and who are the source of information and support (Burt, 1992; Adler and Kwon, 2002). Relational social capital ' $\ldots$ describes the kind of personal relationships people have developed with each other through a history of interactions' (Nahapiet and Ghoshal, 1998: 244). Lastly, cognitive social capital '... refers to those resources providing shared representations, interpretations, and systems of meaning among parties' (Nahapiet and Ghoshal, 1998: 244). For all the possible benefits accruing from social capital little research is available on its influence on the HR function as it interacts with the larger organization.

\section{Research questions}

From the foregoing much research has been conducted on the formal roles of the HR organization. However what remains unexplored is the tangible activities that HR professionals undertake and the level to which these reflect their expected roles, in particular the role of 'strategic business partner'. Moreover, social capital as an organizational resource has been scantily investigated concerning the extent to which it influences the ability of HR professionals to implement HR structures and carry out their intended activities. With regard to the research gap delineated above, the corresponding research questions of this study are as follows:

1. To what extent is the formal structure of the HR organization reflected in the actual activities of HR professionals?

2. To what extent are HR activities influenced by the level of social capital between the HR function and line management?

\section{Literature review}

In the past, researchers produced multiple HR role classifications(see Tyson and Fell, 1986; Storey, 1992; Ulrich, 1997) and investigated whether HR practitioners have been found to be performing all of these roles or only some. Evans et al (2010) categorized the HR function into three roles, namely, Process and Content Development, Service Delivery and Business Support. This structure finds support in the 'HR delivery models' proposed by other HRM scholars (Lawler, Boudreau and Mohrman, 2006; Caldwell, 2008; Ulrich et al., 2008; Wright, 2008) and the roles are reflected in the way MNCs today organize their HR function. Caldwell and Storey (2007) argue that organizing HR in a certain way underlines what is important to the firm such as "which HRM issues will be focused on, measured, and followed up”.

According to Evans et al (2010) 'Process and content development' refers to how HRM policies, practices and processes are developed and thus who is responsible, who is involved, 
and in what capacity. The main purpose of the HR service delivery is to carry out "regular transactional operations connected with HRM, carried out at low cost and with a satisfactory service level” (Evans et al., 2010). 'Business support' refers to the direct ways in which the HR function works with line and top managers on HRM issues. One part of the 'strategic' business support role is to contribute to discussions about people aspects of strategy and organizational capabilities; another may be to work with line/top management on change processes, including organizational redesign.

\section{A Conceptual Framework}

From the foregoing, a conceptual framework of the HR organization on the case company below further clarifies the design of the thesis. Evans et al. (2010) categorized the three roles of the HR function of MNCs into content and process development, service delivery, and business support.

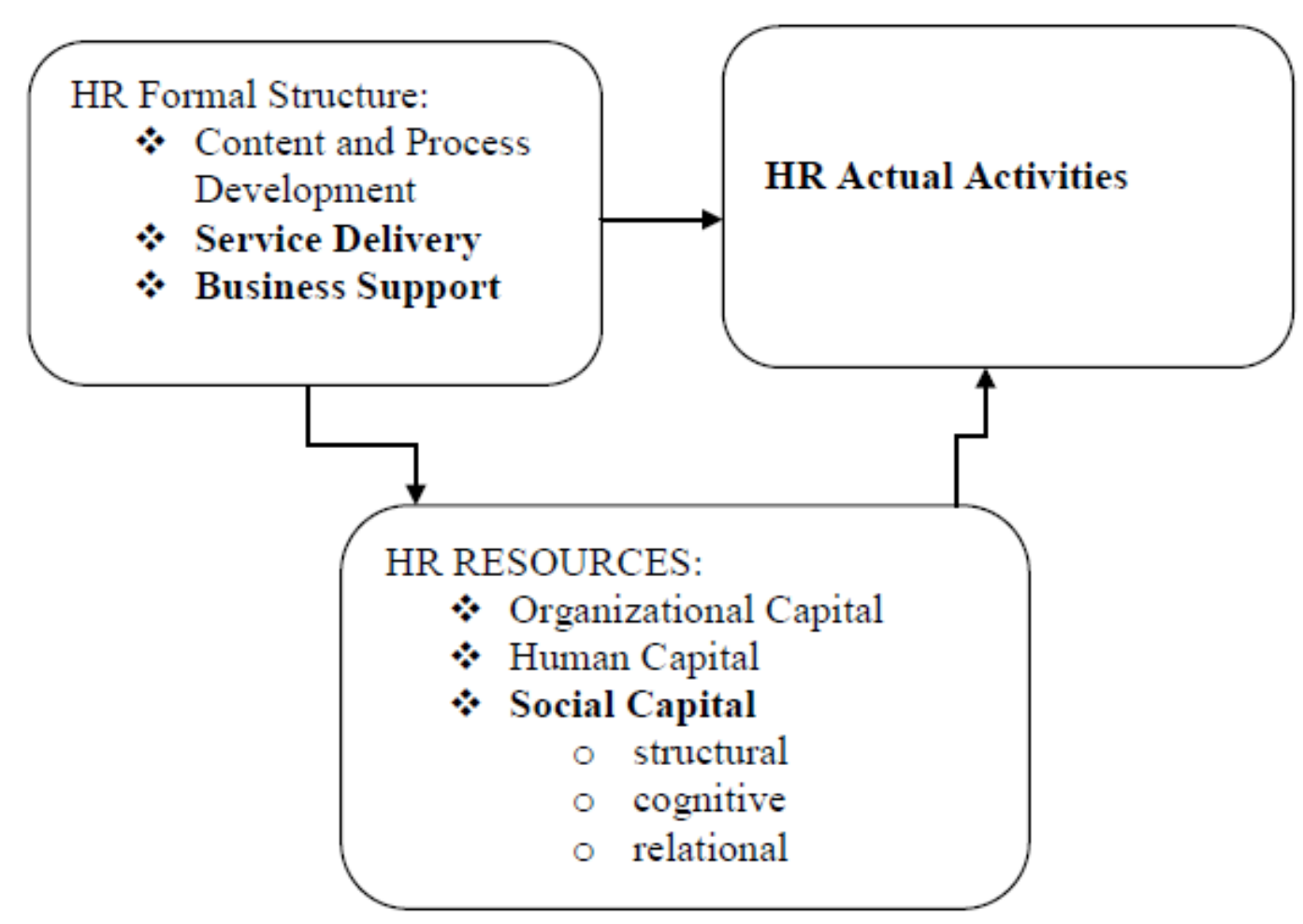

Figure 9. Conceptual Framework of the Study

Ulrich, Younger, and Brockbank (2008) posit that the HR structure is an essential ingredient, enabling the function to align itself with the overall structure of the larger corporation in order to reach its goals and those of the broader firm's strategic goals. Whereas their study focused on strategy versus roles, this study's emphasis is roles versus actual activities. Additionally, despite a considerable body of research on the role of social capital on the HR function, little is known as to the extent to which the social capital between the HR department and the line management influences the actual activities of HR departments.

This paperattempts to apply the classification by Evans et al. (2010), which distinguishes between the process and content development, service delivery, and business support roles of the HR function. Since the content and development role is a function of corporate HR of the case company, only the service delivery and business support roles will be explored in this study. Have these facets of the formal structure of the HR organization been actually 'lived' in the day-to-day activities of HR professionals? How has the HR organization balanced the demands of traditional HRM activities and the need to be strategically focused to the businesses? And how has social capital between HR and the line management impacted the 
extent to which the HR function delivers on its formal roles? Furthermore, the researcher expects to see that activities should correspond to formal roles, but will be influenced by the level of social capital between HR and the line management. These key issues guided the empirical examination of the case company.

\section{Methodology}

Both primary and secondary data were collected for this study. Secondary data in the form of annual reports, working diaries and corporate publications along with information from the firm's website contributed to a rich source of data. Primary data were collected as follows. The Triangulation technique as a key influencing characteristic of the case study implies gathering data from multiple sources for the purpose of obtaining a thorough understanding of the phenomenon under investigation (Ghauri, 2004). However given the thoughts of Ghauri (2004) on the aims of triangulation, other managers were interviewed in addition to HR ones. Specifically, respondent triangulation was used. To ensure accuracy, a few key managers were the focus of the interviews for deep, comprehensive information instead of a large pool of less informed employees (Huber\& Power, 1985). Overall, 5HR and 5 line managers were interviewed between January and March, 2011. Nine were separate interviews and the remaining one was conducted on an HR manager and the assistant. The criterion for selecting HR and line managers was to get a holistic view of the role of the HR function across the three lines, and to facilitate the study on the role of social capital between these two groups of individuals.

Semi-structured interview as a data gathering method was used for two purposes in this research. It wasthe only instrument in conducting qualitative study - interviewing selected HR and line managers. Second, it was also used to discuss the case company's organizational context and human resources management with their HR and/or general manager. The outline of the interview was not fixed in advance completely. Rather, annotationswere deployed from precedent interviews to update and refine the outline, themes and questions as the researcher moved from one respondent to the next. Individual attributes (e.g., demographics, function, and expertise) and individual structural characteristics based on descriptive social network analysis (e.g., centrality, information brokerage roles) were used as criteria for selecting up to ten respondents for interviewing. Respondents' recent experiences in utilizinginformal connections in effecting HR interventions provided the background for probes enabling us to draw valid conclusions as to how social capital influences HRM.

It was desirable for each interview session to last 45 minutes except for instances where an interviewee had more informative experiences to relate. In addition to tape-recording all interviews, the researcher took personal notes. The researcher tried to capture actual activities, opposed to general responses about roles, by asking the interviewees to first of all describe the formal HR structure of the organization. This was followed by a second question to describe their actual activities in a week.

\section{Case background: kanga oy}

Kanga Oy is a subsidiary of Zokko Corporation. Zokko is one of the leading players in the energy markets. Key competitive strengths being technological innovation and comprehensive efficiency, the company has built efficient green solutions. Using the latest cutting edge technology the company furnishes innovative solutions that are efficient, environmentally friendly, and economically viable to customers. With multiple units across the globe, Zokko employs nearly 20000 highly motivated individuals. As a publicly traded firm it is listed in the NASDAQ OMX Helsinki, Finland. 


\section{Kanga Oy-HR organization}

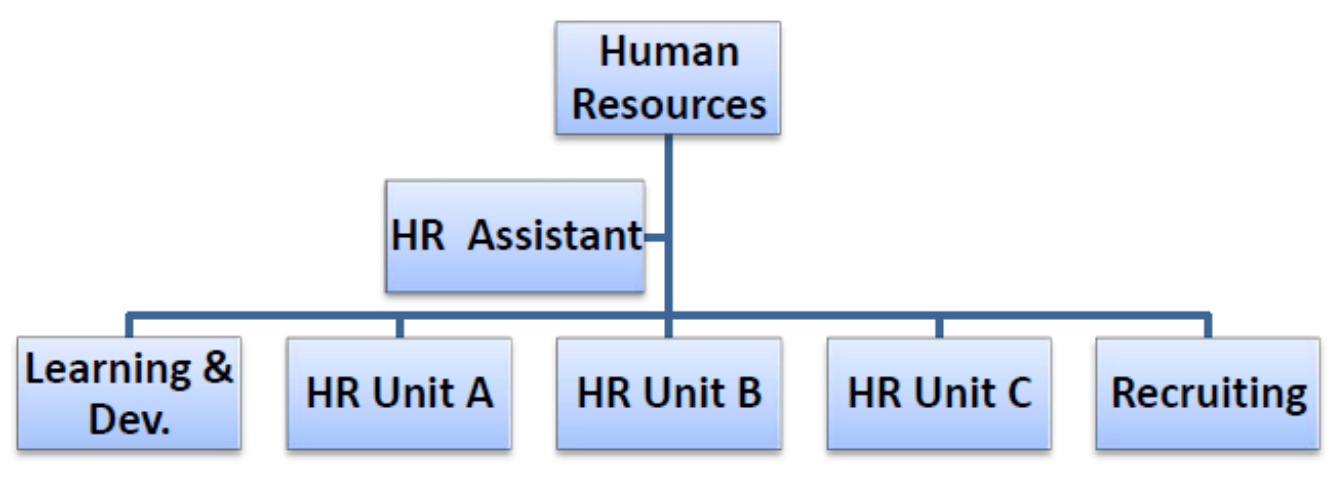

Figure 11. Kanga Subsidiary—HR Organization

The Kanga Subsidiary Company is one of the country-level units and the role of the HR function therein is to carry out HR activities. The HR director for Kanga Subsidiary Company, as depicted in Figure above has jurisdiction over the three HR managers of units A, $\mathrm{B}$ and $\mathrm{C}$, as well as the learning and development, and recruiting managers. In line with the globally integrated HR policy, the learning and development and recruiting managers, seated in unit B, have reponsibility for the respective needs of all three units in the subsidiary.

\section{Findings and discussions}

The empirical data gathered on the actual activities of HR managers revealed mixed outcomes. Both HR and line managers were asked to what extent the HR organization's formal structure was reflected in the actual activities of the department. Resource management, learning and development, processes and systems, and recruitment were the formal HR roles and responsibilities the interviewees enumerated. Other roles identified were remuneration and compensation, strategic HRM, handling safety and legal issues.

The general activity of the HR organization was highly evaluated. To the question as to whether the HR actual activities differed from the formal roles and responsibilities, one line manager responded:

"I think 99\% or 98-99\% they are doing their work very well. Every time we receive our salary in time. They do their work efficiently because I assume that ... they are quite many who have worked quite long time so they know what to do. And also new people they they can mentor them what to do."

(Head:Investigation Group for Technical Services)

Clearly, prompt salary payment, longevity of service and the successful integration of new employees were the reasons assigned for the positive evaluation of HR functional performance. Another encouraging commendation came from a senior line manager who stated:

"I will say, "good" or at least "ok". Most cases I will say we get the support needed. Sometimes we get really really busy, there might be some delay but that's of course there are always resource limitation... They are very knowledgeable in the areas let's say line managers are not so familiar, the timing, the exact details of national agreeements or laws and regulations ... where for sure need expert support.”

(Director, Industrial Operations)

The learning and development team was found to be actively engaged in creating, procuring, and conducting training and developing programs for employees. There was a growing awareness that training provides a way of honing skills, improving productivity and work quality and ensuring employee devotion and loyalty. Progressively, managers are becoming aware that deepening the knowledge, sharpening the skills and competencies of employees is a business necessity that could grant a competitive advantage in recruiting and retaining a high calibre workforce, potentially leading to growth in business. Despite their 
Texila International Journal of Management

Volume 2, Issue 2, Dec 2016

good efforts, line managers complained aboutthe learning and development team's failure to maintain regular contact to assess training and development needs. In addition, presentation materials were either out of date or dysfunctional.

The recruiting team maintained contacts within the community and often participated in job fairs. Contacts were extended to colleges and universities in search for prospective job seekers. Given his extensive stay at the company, the recruiting manager was thoroughly familiar with the firm, the businesses, and the human resources policies of the companies to confidently discuss with potential employees, wages, working conditions and opportunities for development and promotion.

\section{Formal roles versus actual activities}

The focus of the analysis on this section is to discover the extent to which HR professionals were enacting their formal roles and responsibities in daily activities. The analysis starts by presenting and dilating on Tables A-E, summarizing the formal roles versus actual activities of five individual HR managers. The tables have a third column listing the differences between the formal roles and actual activities. The next sections consider in detail the extent to which the actual activities of the HR function are influenced by social capital in reference to social capital theory.

Table A. Global Resourcing Manager

\begin{tabular}{|c|c|c|}
\hline $\begin{array}{c}\text { Formal Structureand } \\
\text { Roles }\end{array}$ & Actual Activities & $\begin{array}{l}\text { Key Differences (if } \\
\text { any) }\end{array}$ \\
\hline $\begin{array}{l}\text { HR Manager: } \\
\text { - Resource } \\
\text { management: global } \\
\text { resourcing of talent } \\
\text { - Learning and } \\
\text { - development } \\
\text { - processes } \\
\text { systems } \\
\text { - recruiting } \\
\text { Response from Line } \\
\text { Manager: } \\
\text { global resourcing---to } \\
\text { explore talent across the } \\
\text { globe. } \\
\text { To cooperate with } \\
\text { regional resourcing } \\
\text { managers in finding } \\
\text { neededresources. }\end{array}$ & $\begin{array}{l}\text { HR Manager: } \\
\text { 1. Production management } \\
\text { meetings } \\
\text { 2. Writing employment contracts } \\
\text { 3. Meeting with production } \\
\text { managers and shop stewards } \\
\text { 4. Open office for employees } \\
\text { 5. CR profit } \\
\text { Line Manager: } \\
\text { Global Resourcing Manager } \\
\text { attends all management meetings: } \\
\text { - DCV Production } \\
\text { Management Team Meetings } \\
\text { - ECOTECH Management } \\
\text { Team Meetings } \\
\text { - PCE Management Team } \\
\text { Meetings } \\
\text { - Info session(for all managers } \\
\text { and shop stewards on } \\
\text { production issues) }\end{array}$ & $\begin{array}{l}\text { A line manager at the } \\
\text { factory maintenance } \\
\text { department } \\
\text { complained this HR } \\
\text { manager was not } \\
\text { proactive during a lay- } \\
\text { off exercise. } \\
\text { Business support by } \\
\text { this HR manager was } \\
\text { insignificant. }\end{array}$ \\
\hline
\end{tabular}

The global resourcing manager defined his responsibility as assessing global human resources needs and identifying appropriate expertise, wherever it could be found, to fill these needs. He would subsequently give recommendations and assistance to the four regional resourcing managers. In addition to this bigger role, he was also expected to liaise with the Kanga local unit line managers on people strategy. There he maintained strong formal linkages with line management by regular presence at management team meetings where he became strategically involved with the businesses. He would get to know what kind of business decisions were made so as to discuss the human resource implications for such decisions. Responding to how he really got line managers to listen to him as a trusted advisor, 
he explained that many people wrongly think that 'shooting straight' is a drawback on your advancement inside the organization. He as well as most other HR leaders reckon the oposite is true. Being forthright with bold confidence is a precondition for being a trusted advisor:

"You must respect the director but you are not allowed to be afraid of the directors; because if you are afraid of directors they are not telling you everything. You must lift yourself almost at the same level with the directors when you are talking. Be polite, kind, but never afraid about directors".

(Global Resourcing Manager)

The implication from models portraying the HR 'business partner' is a stress on consultancy skills. As an internal consultant, the HR 'businesspartner' is regarded as offering suggestions to senior managers and facilitating key organizational changes which include discussing major strategic issues confronting the business (Wright, 2008). Portrayals of the HR 'business partner' as internal consultant also emphasize that this role is only legitimate depending on whether senior management accepts the individuals' proficiency instead of the notion that the HR professional has a formal position from the bureaucratic structure. As a result of the foregoing, the global resourcing manager asserted that those championing the business partner cause should stress the essence for HR managers to cultivate "superior influencing, relationship and networking skills". He argued further that given recent calls within the organization for HR managers to add value to the businesses, he often had to work long hours, often extending working time to the house. He understood his new role as one which should enable him accomplish the goal of elevated status and prestige as a valuable contributor to business issues.

Nonetheless he admitted having to often grapple with the question of whether HR strategy should be aligned to the business strategy or not, and what precisely constituted business support. His concerns corroborated those of the director of industrial operations who pointed out that HR managers had poor knowledge of the businesses. In addition to his strategic role, the global resourcing manager would write employee contracts, which is non-strategic according to his formal role. His activities also included an open office on a weekly basis for employee concerns which is a role for generalists. It appears though his formal tasks and responsibilities included these matters. 


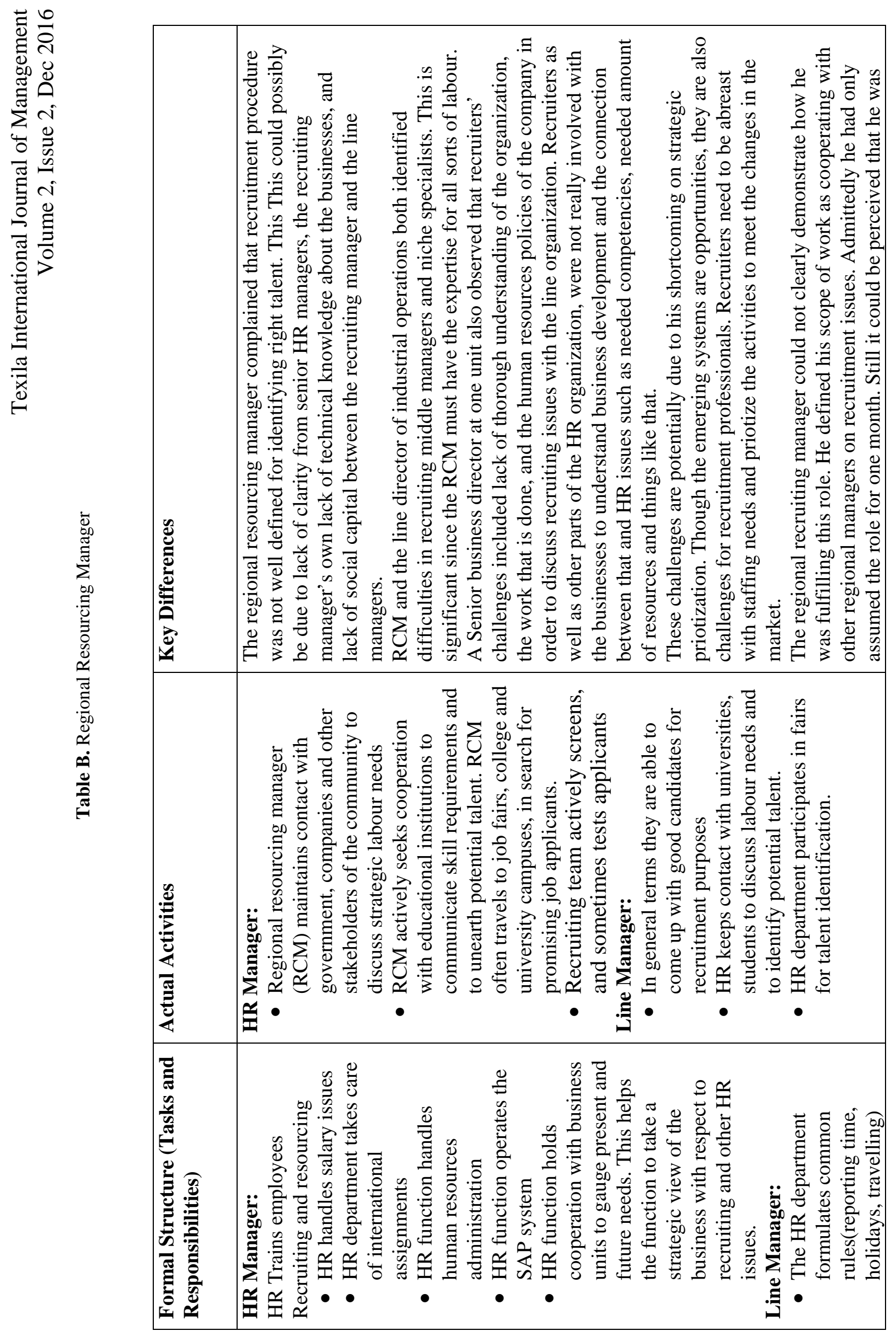




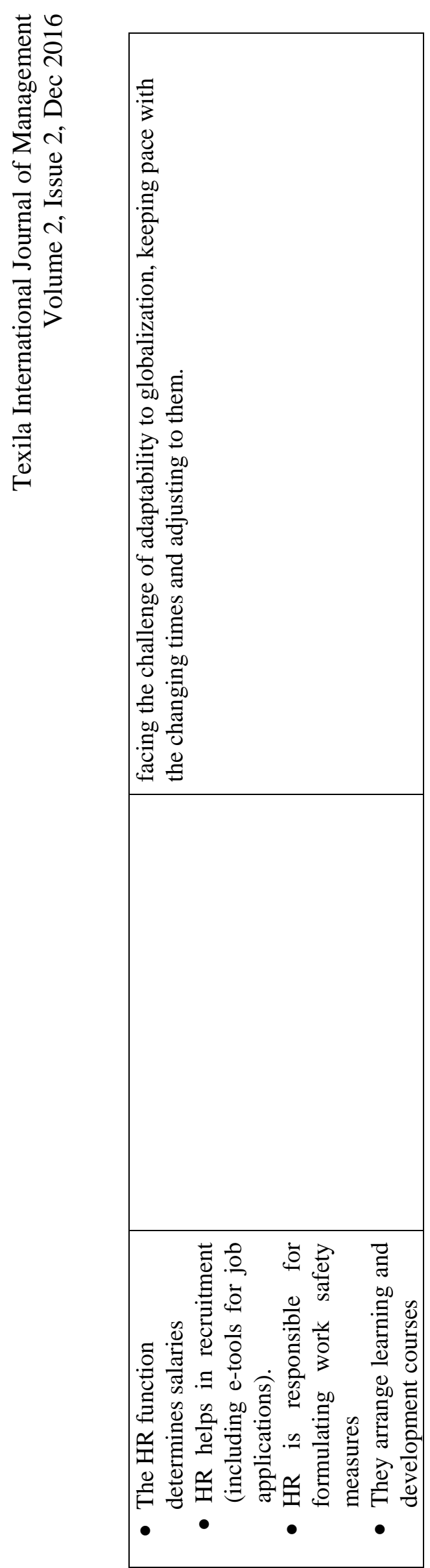

a 
Texila International Journal of Management

Volume 2, Issue 2, Dec 2016

The recruitment managerwas generally commended for fulfilling his roles. Reacting to a question on feedback from the clients, he said:

At least when ask feedback they have told us that they(business managers) are quite satisfied. Naturally there are things to develop but things are quite positive.

(Regional Resourcing Manager)

This assertion was backed by some line managers one of whom declared the actual activities of the resourcing manager reflected his formal responsibilities, though recent layoffs from the HR department meant more HR matters were henceforth devolved to the lines:

We have very good communication with the recruiting side. But the problem now is we have some difficulties, recently we laid off some people so if you have recruitment going on......If we talk about training issues, competence development I think we [line managers] have to be more active in the business. The line managers have to be more active than before, since we don't have this competence training er ladies sometimes push us to: "Now we have to do this; Do you have some need?" Now we have to be alert ourselves. So in that respect I think the work is shifted to the line organization. That is how I see it.

(Director, Supply Market Management)

His shortcomings and challenges were identified by both himself and line managers, as reported in Table E. 


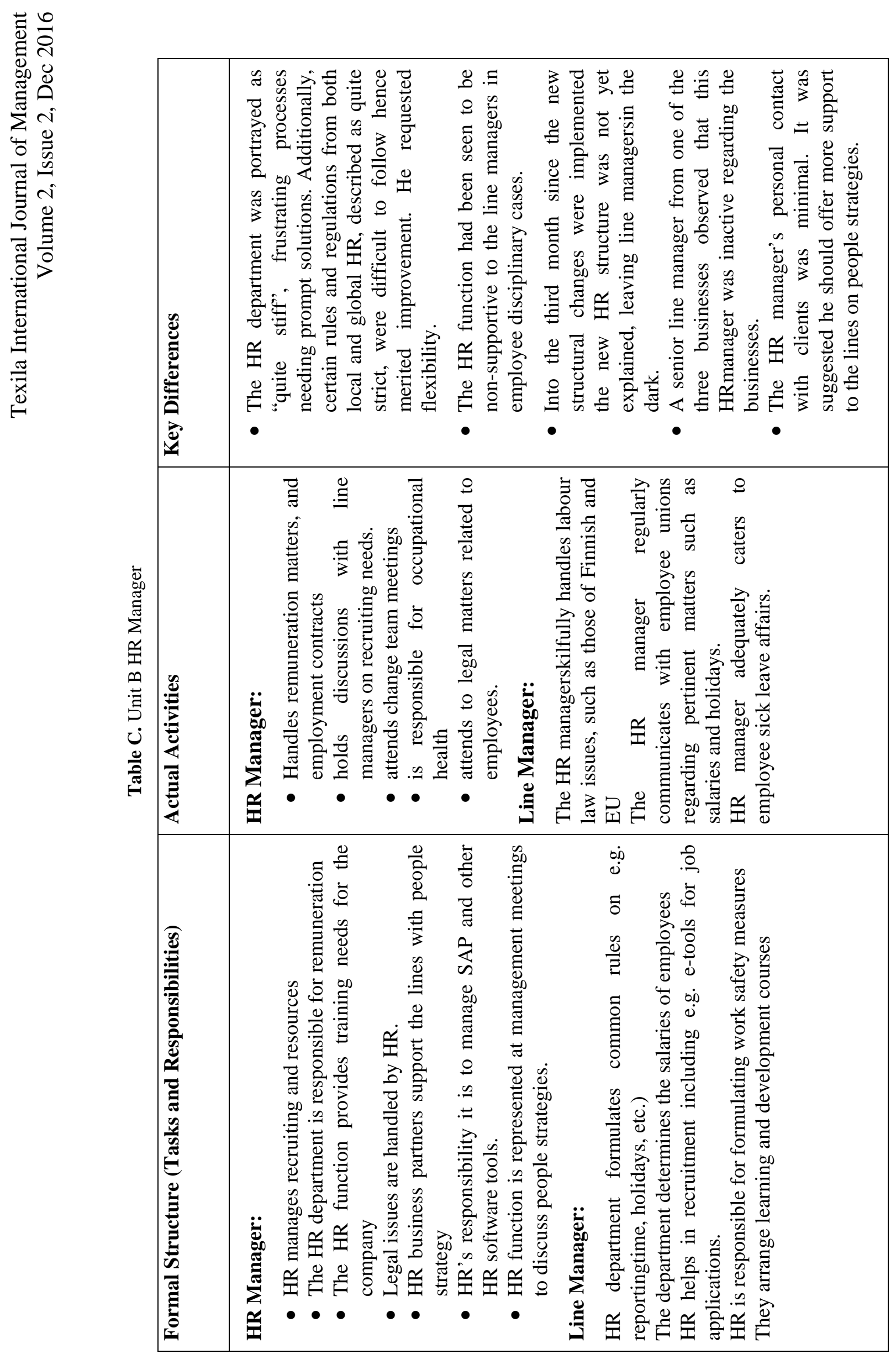


Unit B HR manager is a generalist who specialized in compensation, benefits, and legal affairs. Like others managers, he was perceived to fulfilling his roles. In addition he was coordinating HR activities in positive ways; he had a regular presence at management team meetings where he had opportunities to discuss HR matters on strategy. Despite this the services maintenance manager complained HR professionals did not actively get involved with the businesses. And incidentally, the HR manager gave little explanation on how much he offered at the meetings on business strategic goals. He described himself as an "oldfashioned generalist". However, attending management team meetings enatailed his work was both administrative and strategic. Could this be owing to a lack of clear-cut direction on business support from his superiors?

His lack of understanding of business support apparently led to complains from line management to the effect that certain HR policies were not properly communicated. One instance was the concern that policy changes on travelling and maternity leave had not been well communicated. Another probably more serious concern came from the supply marketing manager. He bemoaned that very helpful HR business professionals were recently withdrawnfrom the lines. HR staff withdrawal was part of a restructuring exercise, but evidently this was not adequately communicated to the lines. It had become a corporate policy to devolve much of the HR issues to line managers. Apparently lack of clarity from senior HR managers, including this one, potentially contributed to the lapse. Alternatively it might simply be faliure on responsible managers' part to explain policy changes fully as proposed by a line manager. Interestingly, both this HR manager and line managers alike testified that the HR function was now overstreched, having lost many of the staff through redundancy.

Several more shortcomings of this HR manager were recounted by line management. HR software systems such as SAP and SABA, were reportedly not user friendly. Moreover, presentation templates and other materials were described as non user-friendly and out-dated. A recent survey named, MY VOICE, was said to be badly administered. Too many managers were involved with the data analysis rendering the exercise rather expensive. The supply marketing manager intimated this HR manager failed to realize prevailing low remuneration levels which demotivated employees. Line managers stated there was lack of mental support for project managers from the HR manager. Many projects were challenging, exhausting and depressing. In times line managers really needed some emotional support from the HR department, this was not forthcoming. Futhermore, a line manager from the services business complained HR information in the intranet was scattered hence difficult to find and suggested it should be well organized. This HR manager was expected to take note of these developments since HR issues were under his oversight.

Table D. Unit A HR Manager

\begin{tabular}{|c|c|c|}
\hline $\begin{array}{l}\text { Formal Structure } \\
\text { (Tasks(roles) and } \\
\text { Responsibilities) }\end{array}$ & Actual Activities & Key Differences \\
\hline $\begin{array}{l}\text { Tasks and } \\
\text { responsibilities: } \\
\text { HR Manager: } \\
\text { - HR cares for all } \\
\text { kinds of personnel } \\
\text { matters } \\
\text { - HR is responsible } \\
\text { for all recruitment } \\
\text { - It is HR's role to } \\
\text { deal with salaries } \\
\text { - HR plays an } \\
\text { advisory role for line } \\
\text { managers and }\end{array}$ & $\begin{array}{l}\text { HR manager: } \\
\text { - makes new } \\
\text { contracts, } \\
\text { - discusses with the } \\
\text { shop } \\
\text { stewards(employee } \\
\text { representatives) the } \\
\text { concerns } \\
\text { employees of } \\
\text { - discusses with } \\
\text { different managers } \\
\text { matters of concern in }\end{array}$ & $\begin{array}{l}\text { A line manager from the } \\
\text { production maintenance } \\
\text { management observed that } \\
\text { administrative matters had been } \\
\text { devolved to the line. This might } \\
\text { be as a result of change in } \\
\text { corporate policy, but the lines } \\
\text { remained disinformed. } \\
\text { The line director of industrial } \\
\text { operations added that occasional } \\
\text { special case HR matters were left } \\
\text { to the line, such as a returning } \\
\text { employee from long illness. }\end{array}$ \\
\hline
\end{tabular}




\begin{tabular}{|c|c|c|}
\hline $\begin{array}{l}\text { employees } \\
\text { - HR takes } \\
\text { responsibility for } \\
\text { people strategy } \\
\text { Line Managers: } \\
\text { - HR attends to legal } \\
\text { matters } \\
\text { - HR does recruitment } \\
\text { for the company } \\
\text { - HR is responsible } \\
\text { for employee health } \\
\text { and safety } \\
\text { - HR is responsible } \\
\text { for signing all } \\
\text { contracts of new } \\
\text { employees } \\
\text { - HR negotiates } \\
\text { salaries and wages } \\
\text { according } \\
\text { corporate policies } \\
\text { - HR is responsible } \\
\text { for regular dialogue } \\
\text { with unions and } \\
\text { shop stewards } \\
\text { - Employee statistics } \\
\text { are handled by } \\
\text { HR(for purposes of } \\
\text { monitoring e.g. sick } \\
\text { leaves, and doing a } \\
\text { follow-up) } \\
\text { - HR representative } \\
\text { attends Management } \\
\text { Team(MT) meetings } \\
\text { to update MT } \\
\text { members on HR } \\
\text { issues, e.g. relaying } \\
\text { new guidelines from } \\
\text { Headquarters) }\end{array}$ & $\begin{array}{l}\text { the lines } \\
\text { - keeps in contact with } \\
\text { different } \\
\text { management teams } \\
\text { - occasionally does } \\
\text { staff reshuffles } \\
\text { Line Managers: } \\
\text { - administrative } \\
\text { matters have been } \\
\text { devolved to the line }\end{array}$ & $\begin{array}{l}\text { Some returning workers would } \\
\text { do overtime work right on the } \\
\text { day they would have resumed } \\
\text { work. } \\
\text { Other key differences included } \\
\text { inappropriate development } \\
\text { projects for employees, } \\
\text { insufficient job description for } \\
\text { workers, lack of mechanisms for } \\
\text { reviving demotivated workers, } \\
\text { occasional employee disruptive } \\
\text { behaviour inadequately handled, } \\
\text { and poor communication during } \\
\text { redundancy exercise in } 2010 . \\
\text { A production line manager } \\
\text { reported that additional causes } \\
\text { for concern were HR managers' } \\
\text { apparent lack of grasp of labour } \\
\text { laws and the struggle of new } \\
\text { managers to integrate. New } \\
\text { managers were largely left on } \\
\text { their own to find their way. }\end{array}$ \\
\hline
\end{tabular}




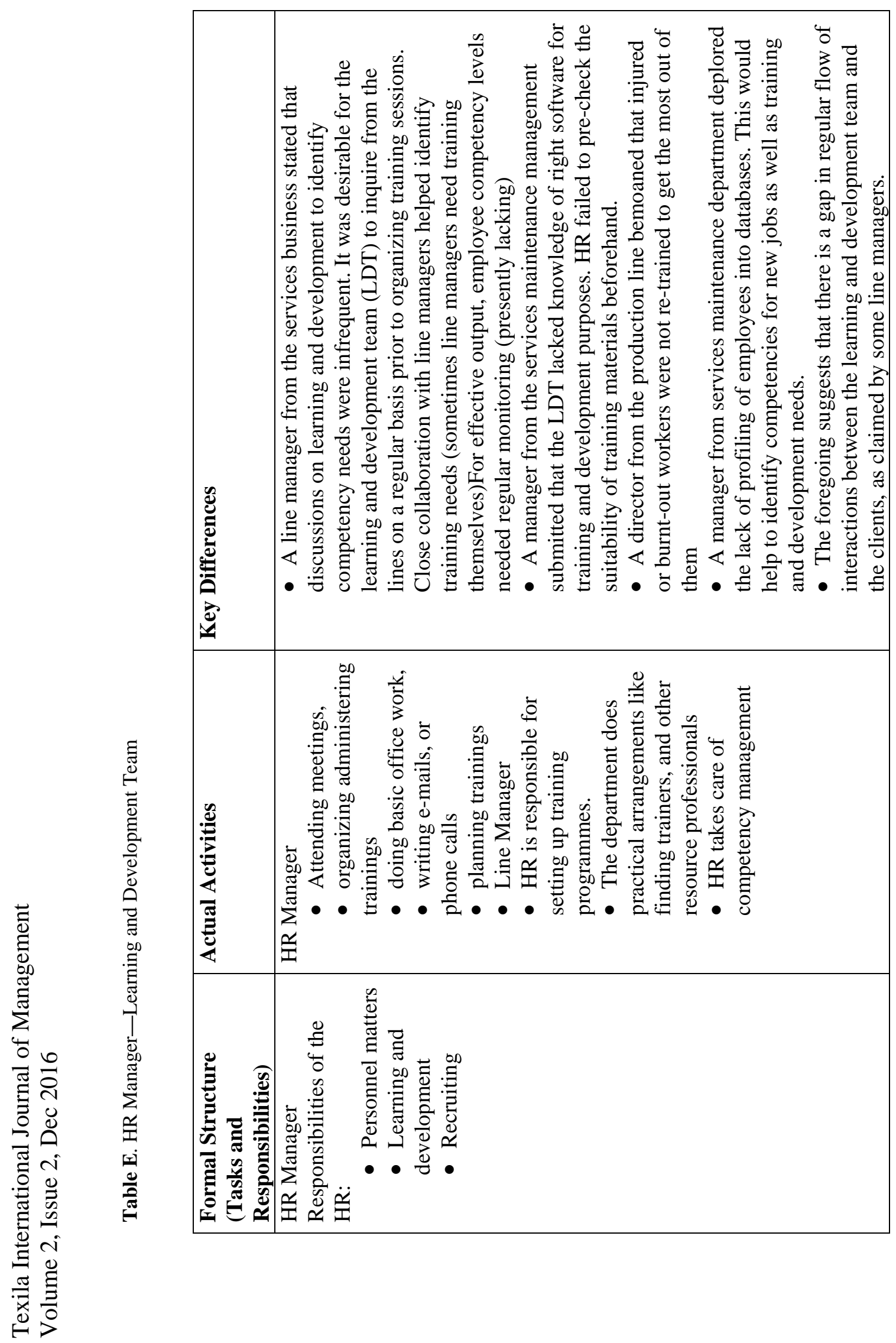


The learning and development received mixed report from the lines despite the team leader thinking their clients felt the team was enacting its formal roles well. The team leader observed:

"I have to say that customers are very happy... We usually don't have any challenges or problems with line management or ... because I think with training they're usually very happy. And if they like to have some improvement we will always try to find out the solution. So I think it is working very well.

(Learning and Development Manager)

On the other hand, although line managers said the actual activities of the learning and development team reflected their formal roles to some extent, certain aspects were not fully accomplished. One line manager recommended a "little more activity from their side[Learning and Development's] with regard to ... training”. Another one from the services business was critical of the training tools and equipment:

"HR lack knowledge of the right software for training and development. They fail to precheck the suitability of training materials before hand. They must collaborate with line managers in identifying needs before prescribing training. Sometimes it is the line managers themselves needing training."

(Services Maintenance Management)

\section{The structural features of social capital}

The focus of this section is to examine the degree to which the structural feature of social capital between the HR function and line management was shown to influence HR's ability to enact their roles. In other words, the goal is to establish the extent to which HR's actual activities were influenced by social capital. Table $\mathrm{J}$ uses the social capital lens to explain the differences arising from HR's formal roles vis-à-vis actual activities performed.

Table F: External Structural Components of Social Capital

\begin{tabular}{|c|c|}
\hline & \\
\hline $\begin{array}{l}\text { Business support by HR department } \\
\text { was insignificant ;HR function was inactive } \\
\text { regarding the businesses ; HR managers' } \\
\text { personal contact with clients was minimal ; } \\
\text { there were calls from line management on } \\
\text { HR to offer more support to the lines on } \\
\text { people strategies. }\end{array}$ & $\begin{array}{l}\text { - Social capital is a plausible } \\
\text { explanation, that is, HR managers poor } \\
\text { relationships with corporate and line } \\
\text { management or disagreements about the } \\
\text { purpose and identity of the strategic role of } \\
\text { HR. Other limiting factors on the manager's } \\
\text { ability to be strategic might include personal } \\
\text { competence and personal characteristics such } \\
\text { as his educational background. These are } \\
\text { crucial in dealing skilfully with the lines, } \\
\text { reflecting the diversity of duties and levels of } \\
\text { responsibility. Also human resources } \\
\text { occupations require strong interpersonal skills } \\
\text { which might be lacking in a manager whose } \\
\text { background was not based on personal } \\
\text { interactions. }\end{array}$ \\
\hline $\begin{array}{l}\text { - HR department was inactive during } \\
\text { lay-off exercise. The HR department was } \\
\text { portrayed as "quite stiff", frustrating } \\
\text { processes needing prompt solutions. HR was } \\
\text { also seen as non-supportive to line managers } \\
\text { in employee displinary cases. }\end{array}$ & $\begin{array}{l}\text { - HR's inactivity could partly be } \\
\text { explained by a lack of social capital between } \\
\text { HR and line managers. It could also be } \\
\text { explained by certain bottlenecks in the } \\
\text { implementation of structural change, or other } \\
\text { factors relating to e.g. the competence of HR } \\
\text { professionals. }\end{array}$ \\
\hline
\end{tabular}




\begin{tabular}{|c|c|}
\hline $\begin{array}{l}\text { - Into the third month since the new } \\
\text { structural changes were implemented the } \\
\text { new HR structure was not yet explained, } \\
\text { leaving line managers in the dark. }\end{array}$ & $\begin{array}{l}\text { - A lack of clarity from senior } \\
\text { managers possibly contributed to the } \\
\text { deficiency. At the time of the interviews, the } \\
\text { company was just one month implementing a } \\
\text { new organizational structure. The HR } \\
\text { organization was changed from multi- } \\
\text { domestic to a globally integrated one. This } \\
\text { state of affairs confused HR managers as to } \\
\text { the exact scope and details pertaining to their } \\
\text { new roles job. And as always, low levels of } \\
\text { social capital between HR function and line } \\
\text { management was a contributory factor. }\end{array}$ \\
\hline $\begin{array}{l}\text { Administrative matters had been } \\
\text { devolved to the line }\end{array}$ & $\begin{array}{l}\text { Line managers might not want the } \\
\text { increased responsibility for HRM, might not } \\
\text { have time to deal with this role properly, or } \\
\text { might lack the capacity and current functional } \\
\text { knowledge on HRM issues. Possible reasons } \\
\text { for the devolvement are cost reductions and } \\
\text { more importantly, to focus on developing } \\
\text { leadership competencies of HR professionals. } \\
\text { Nonetheless, HR's failure to communicate this } \\
\text { important change in policy could be } \\
\text { attributable to the function's weak social } \\
\text { capital with the line. HR managers weak } \\
\text { personal competence and lack of regular flows } \\
\text { of latest HR information from senior HR } \\
\text { managers are other potential factors. }\end{array}$ \\
\hline $\begin{array}{l}\text { Inappropriate development projects } \\
\text { for employees, insufficient job description } \\
\text { for workers, lack of mechanisms for } \\
\text { reviving demotivated workers, were further } \\
\text { line concerns. }\end{array}$ & $\begin{array}{l}\text { - Again these instances of failure on the } \\
\text { part of the HR manager could be attributable } \\
\text { to the absence of social capital between him } \\
\text { and the line managers. Personal characteristics } \\
\text { such as shyness, lack of enthusiasm or } \\
\text { confidence might also be contributory factors. }\end{array}$ \\
\hline $\begin{array}{l}\text { Discussions on learning and } \\
\text { development (LDT) to identify competency } \\
\text { needs were infrequent. LDT lacked } \\
\text { knowledge of right software for training and } \\
\text { development purposes. Training materials } \\
\text { were unsuitable. }\end{array}$ & $\begin{array}{l}\text { - Plausible explanations for this state of } \\
\text { affairs are presented below. Eventhough the } \\
\text { learning and development manager stated her } \\
\text { team received positive feedback from clients, } \\
\text { she admitted her team only had minimal } \\
\text { contact with the lines at informal levels. This } \\
\text { indicates a lack of social capital with the lines. } \\
\text { Informal relationships are a powerful force to } \\
\text { receiving more accurate feedback. Formal } \\
\text { feedback carries a risk. Clients might simply } \\
\text { want to avoid stepping on toes, hence would } \\
\text { decide to give positive feedback. }\end{array}$ \\
\hline
\end{tabular}

It summarises the findings as reported in Tables $\mathrm{D}$ to $\mathrm{H}$, offering possible explanations as to the differences between HR's formal roles and actual activities. It could be inferred from those tables strong formal structures to connect the HR department and line management. Still the differencesseen between expected roles and HR professionals' concrete daily activities merited explanation. Structural social capitalinvolves the inter-relationship between the HR department and the larger subsidiary organization, such as HR functional participation at meetings and processes designed to "link" the HR department with the organization. As depicted in Table J, major gaps were found between HR's expected and actually enacted roles 
despite the function's strong formal linkages to the line organization. It was found that HR managers had various degrees of connection to the line organization, making visible efforts to generate formal links between the function and the lines:

"I will saylocal HR managers' role... to cooperate with er with er different level of organization is quite important. First of all, The HR Director of Kanga is a member of Kanga Management Team. And these directors are members of local management teams. For example I used to be a member of Kanga R\&D Management Team as well as Kanga Production Management Team. And he[Unit B HR manager] should be So-so-and-so Management Team and Services Management Team. So when you're part of the management team, you know what kind of business decisions will be and when you know business decisions then you can adjust the HR issues, that you cooperate and align your strategy to the business strategy."

( Global Resourcing Manager)

The strategic managers regularly participated at meetings with various business management teams. For instance, the global resourcing manager seemed to have been the most involved HR manager at the meetings, doing so severally in a week. He stated:

"I used to be a member of ......R\&D Management Team as well as Production Management Team. ...................... So when you're part of the management team, you know what kind of business decisions will be and when you know business decisions then you can adjust the HR issues, that you cooperate and align your strategy to the business strategy. There is always a question that should the business strategy and HR strategy...should they be er er aligned or should they be same?"

(Global Resource Manager)

Other forms of the HR function's contact with the lines were evident. Reacting to a question on how the lines met with the HR department, one line manager stated:

"The formal part, the important one is the monthly DCV Management Team meeting, that is one thing, but of course there are more that are unofficial. By phone, by mail"

(Line Director, Industrial Operations)

Involving the HR function at line formal meetings was viewed as a priority. A line manager at unit $B$ explained that there was always a seat for the HR Manager where he presented HR strategy:

Actually we have we're arranging this PP information event every quarter and then half a year back we have Markku as the permanent speaker; he always has time 15 min to half hour to talk about HR issues; there is always something happening there. Then also they get direct information from our businesses, what is our need?

(Director, Supply Market Management)

In unit A, the HR department is located in a block housing the production, $R \& D$ and logistics departments where the respective line managers also are. This physical proximity makes it convenient for formal and informal interactions. Commenting on the convenience of having the HR function close to the businesses, a line manager related:

"Hannu is sitting quite next here so it is easy for him to come down here or for me going there .... in that sense of course it's quite easy to arrange."

(Director, Industrial Operations)

Echoing this, another line manager had this to say:

“No, usually no problem for me it's almost good location, they're just a floor up from here, so I don't find it difficult Mika Palosaari is located in Unit B, but Kangais such a huge company. In Kanga it's not possible to have everybody under one roof. That's why we have 2 locations, Mika is over there but we have local HR here. It would be much more difficult if the HR people is totally in Unit B or "

(Production Maintenance Manager)

On the modes of contact between the lines and the HR department, managers from both sides concurred that both sides used phone calls, e-mails and face-to-face meetings as modes 
Texila International Journal of Management

Volume 2, Issue 2, Dec 2016

of communication, depending on the urgency and gravity of the situation at hand. A line manager recounted:

"Many timesat first I try to call but also they are sometimes hard to reach; after that I should e-mail. Of course sometimes when we need new faces and we have to make the contract with new employee then it's face-to-face”

(Director, Supply Market Management)

Another line manager confirmed:

"Mostly I call them, but er I have also used e-mail...when I have to get the solution at that place---within certain minutes I have to get the answer then I take call. And also when the matter is a little bit bigger I call if you have time and then I have face-to-face meeting. That is quite seldom-once in 2 years, excluding these recruitments."

(Services Maintenance Manager)

The foregoing analysis showed that HR managers and professionals used definite structures to keep links with the line organization. These included formal management meetings, phone calls, e-mails and one-on-one meetings. Thus to a reasonable degree, structural social capital was strong between the lines and HR. Despite those positive developments certain appeals were made regarding HR's weak cooperation with line management in business support. Some line managers indicated more HR involvement with the lines was needed:

"Support, one thing that should be a little bit more, maybe support for the managers in HR issues and I think it's very difficult when you have problematic issues in the company or with some employee and so on. But I have not realized it myself but I could imagine that in that respect it should a little bit more. More cooperation and discussion and if you have problematic issues"

(Director, Supply Market Management)

Apart from calls for more business support, concerns were raised respecting certain administrative issues. Intranet sites and news letters used by HR managers to communicate current HR issues to the lines were inconveniently mixed with the company's general information. Hence one line manager criticised the approach, arguing it took a great deal of time searching for HR information. The intranet is fraught with a maze of information from all divisions, including HR. One could spend all working time looking for certain information. He suggested ways to improve this situation, including information sessions and subsequent regular reminders. He observed :

"I have missed some very important information and that's why it's good to have ... organized information".

(Head, Technical Services)

Other concerns raised included the lack of clarity in communicating policy changes. Calling face-to-face meetings with managers for the purpose of briefing them on new changes and repeating these in other forms to achieve full awareness would be a welcome relief. Furthermore, key matters such as maternity leave should be put in the intranet for easy access. It should also be a good practice if HR professionals could informally communicate HR initiatives to line clients. This would obviously help forestall the frustrations associated with misinformation and disinformation. Commenting on the frustration resulting from misinformation, one line manager recalled:

“' 'Yes, yes it's ok to have two years maternity leave'...Then you go to your place and and 'sorry, sorry, very sorry you only have 11 months and the mother is 'Oh no! What a shit! You promised me ... two years and now you're saying that you'll only get 11 months?'In that, to avoid that kind of situations it's good to have that kind of information where Rautonen or somebody else is giving, 'Now maternity leave has now changed from this number of months to this number of months.",

(Head, Technical Services) 


\section{Conclusion}

Previous research on HRM has implied that HR strategies, policies and the way the HR departments function may influence their effectiveness (Buyens and de Vos, 2001; Murphy and Southey, 2003). And extant contributions to this debate have focused mainly on what HR departments do, instead of outrightly reporting on the extent to which the actual activities of HR professionals reflect the formal HR organization. Furthermore, existing contributions have said little on the influence of social capital on HR function's actual activities. For these reasons presently, it has been impossible to ascertain whether HR roles are notable and why, and how significant the impact of social capital is for HR departments in successfully performing their roles and responsibilities.

The finding showed the HR function was highly evaluated for administrative tasks. However, strong calls were made on HR to increase their involvement with a particular focus on activities related to the business support role. There appeared to be a connection between HR social capital and the actual activities of the HR organization. Although strong formal linkages between the HR function and line management were evident, the level of informal relationships was weak between them. This is a slice of case study research in a subsidiary, and therefore the findings may not be generalizable. Further quantitative research is recommended. The practical implication for HR professionals is that careful consideration should be taken in observing how social capital between the HR function and the larger organization adds value.

\section{References}

[1]. Adler, N.J. and Bartholomew, S. (1992). Managing globally competent people. Academy of Management Executive6 (3), pp. 52-65.

[2]. Adler, P., \& Kwon. S.W. (2000). Social Capital: The Good: The Bad and the Ugly. In Lesser, E.L. (Ed.), Knowledge and Social Capital Foundations and Applications 69-87.

[3]. Adler, P. \& Kwon, S. (2002). Social capital: prospects for a new concept. Academy of Management Review, 27, 17-40.

[4]. Balogun, J., Jarzabkowski, P. \& Seidl, D. (2007). Strategizing: A Practice Perspective. Human Relations, 60:1, tbd.

[5]. Baron J. \& Kreps D. (1999). Strategic Human Resources-Frameworks for General ManagersNew York: Wiley.

[6]. Brewster, C. \& Larsen, H.H. (1992). Human Resource Management in Europe: Evidence from ten countries. The International Journal of Human Resource Management, 3: 409-433.

[7]. Burt R. S. (1992). Structural Holes. Cambridge, MA: Harvard University Press.

[8]. Burt, R.S. (1997). The contingent value of social capital. Administrative Science Quarterly, 42, 339-365.

[9]. Buyens, D. \& De Vos, A. (2001). "Perceptions of the value of the HR function". Human Resource Management Journal.11: 3, 70-89.

[10]. Caldwell, R. \&Storey, J. (2007). The HR function: Integration or fragmentation? Human resource management: A critical text. London: Thomson. 2138.

[11]. Caldwell, R. (2008). HR business partner competencies models: Re-contextualising effectiveness. Human Resource Management Journal. 18:3, 275-294.

[12]. Easterby-Smith, M., Thorpe, R., \&Lowe, A. (2002). Management Research: An Introduction (2 ${ }^{\text {nd }}$ edn). London: Sage

[13]. Evans, P., Pucik, V., and Björkman, I. (2010, in press). Global Challenge: International Human Resource Management ( $2^{\text {nd }}$ edition), New York: McGraw-Hill.

[14]. Ghauri, P. (2004). Designing and conducting case studies in international business research. In: Handbook of Qualitative Research Methods for International Business, 109-124. Eds R. MarschanPiekkari and C. Welch. Cheltanham: Edward Elgar Publishing, Ltd.

[15]. Golsorkhi, D., Rouleau L., Seidl D., \& Vaara, E. (2010). Cambridge Handbook of Strategy as Practice. Cambridge: Cambridge University Press. 
Texila International Journal of Management

Volume 2, Issue 2, Dec 2016

[16]. Gratton, L. and Truss, C. (2003). “The three-dimensional people strategy: putting human resources policies into action”. Academy of Management Executive. 17:3, 74-86.

[17]. Guest, D. \& King, Z. (2004). Power, Innovation and Problem-Solving: The Personnel Managers' Three Steps to Heaven? Journal of Management Studies. 41: 3, 401-423

[18]. Huber, G.P. \& Power, D.J. (1985). "Retrospective reports of strategy-level managers: guidelines for increasing their accuracy”. Strategic Management Journal.6, 171-80.

[19]. Jarzabkowski, P. (2002). "Centralised or decentralised? The strategic implications of resource allocation models."Higher Education Quarterly, 56:1, 5-32.

[20]. Lawler, E. \& Mohrman, S. (2003). "HR as a strategic partner: what does it take to make it happen?” HR Planning. 26: 15-30.

[21]. Lawler E.E., Boudreau, J. \& Mohrman, S.A. (2006). Achieving Strategic Excellence. Stanford: Palo Alto.

[22]. Murphy, G. \& Southey, G. (2003). "High performance work practices: perceived determinants of adoption and the role of the HR practitioner”. Personnel Review.32 : 1/2,73-92.

[23]. Nahapiet, J., \& Ghoshal, S. (1998). Social capital, intellectual capital, and the organizational advantage, Academy of Management Review. 23, 242-266

[24]. Snell, S. (1999). “Social capital and strategic HRM: it's who you know”. Human Resource Planning, 22: 62-4.

[25]. Sparrow, P., Harris, H., \& Brewster, C. (2003). Towards a new model of globalizing HRM. Paper presented at the 7th Conference on International Human Resource Management, University of Limerick, Ireland.

[26]. Storey, J. (1992). Developments in human resource management. Oxford: Blackwell.

[27]. Tsai, W. (2000).“Social capital, strategic relatedness and the formation of intra-organizational linkages”. Strategic Management Journal. 21: 925-39

[28]. Tyson, S., \& Fell, A. (1986). Evaluating the personnel function. London: Hutchinson.

[29]. Ulrich, D. (1997). Human Resource Champions - The Next Agenda for Adding Value and Delivering Results. Harvard Business School Press. Boston, MA.

[30]. Ulrich, D., \& Brockbank, W. (2005). Role call. People Management. 11:12, 24-28.

[31]. Ulrich, D., Y o u n g e r, J. \& Brockbank, W. (2008). The Twenty-First-Century HR. Human Resource Management. 47: 4, 829-850

[32]. Wright, C. (2008). 'Reinventing human resource management: business partners, internal consultants and the limits to professionalisation’. Human Relations, 61: 8, 1063-1086. 